Canadian Studies in Population, Vol.34.2, 2007, pp. 217-240

\title{
Does Divorce Risk in Sweden depend on Spouses' Relative Income? A Study of Marriages from 1981 to 1998
}

\section{Guiping Liu}

Centre for Youth \& Society

Department of Psychology

University of Victoria,

Victoria, BC, Canada

gliu1@ telus.net

Andres Vikat

Population Activities Unit

United Nation Economic Commission for Europe

Geneva, Switzerland

\begin{abstract}
The relationship between increasing women's earnings and rising divorce rates frequently has been explained by the so-called independence effect: If a wife enjoys a higher earning than her husband does, she gains less from marriage. It has also been argued that in a society with egalitarian gender attitudes this effect is less important. In this paper, we test if the independence effect applies to Sweden, a country in which egalitarian gender views dominate and female labour-force participation and divorce rates are high. Our analysis is based on a large register data set and intensity regression models. We found support for the 'independence effect': The relationship between the share of a wife's income and the divorce risk is positive regardless of the couple's total income and the wife's education level.
\end{abstract}

Key Words: divorce, gender equity, relative income, Sweden 
Guiping Liu and Andres Vikat

\section{Résumé}

La relation entre l'augmentation des salaires des femmes et le taux de divorce a souvent été expliqué par le soi disant «effet de revenu »: Si une femme gagne un salaire plus élevé que celui de son mari, le mariage lui apporte moins d'avantages . Il a aussi été argumenté que cet effet est moins prononcé dans une société qui prône des attitudes égalitaires entre les sexes. Dans cet article, nous avons testé si l'effet de revenu s'applique à la Suède, un pays où l'égalité des sexes prédomine, où le nombre des femmes qui participent à la main d'oeuvre et le taux de divorce sont élevés. Notre analyse se base sur un grand registre de données et sur des modèles de regression d'intensité. Nous avons trouvé que la théorie de «l'effet de revenu » a du mérite. La relation entre la part de salaire de la femme et le risque de divorce est positive et cela, indépendément du salaire total du couple ou du niveau d'éducation de la femme.

Mots-clés : divorce, égalité des sexes, revenu relatif, la Suède

\section{Introduction}

Women's participation in the labour force and divorce rate has been increasing in parallel in recent decades. The rise in divorce rates accelerated in the second half of the 1960s and in the 1970s throughout the western world. The past decades have also witnessed a marked flow of women into the labour market. Sociological and economic theories (Parsons, 1949; Becker, 1981) have suggested a causal relationship between the changing economic roles of women and the rise in divorce, and a large body of literature on this topic has emerged over the last couple of decades. More recently, empirical studies based on micro-level survey data on both spouses have brought much more insight into this topic, however, they have not lead to a clear-cut overall conclusion (for recent literature reviews, see Sayer \& Bianchi 2000, Rogers 2004).

The ample literature on the relationship between wives' labour-force attachment and marital stability has been dominated by studies based on data from the United States, and framed by the micro-economic and sociological family theories, in the context of the mid- $20^{\text {th }}$ century U.S., as the starting point. In this article, we also begin with these theoretical arguments; however, empirically, the relationship between spouses' income and marital stability in Sweden is examined, a country that differs from the U.S. in many pertinent ways. In particular, the differences concern the domination of egalitarian gender views, 
high female labour-force participation rates and the strong ideational and policy support to the dual earner family in Sweden where divorce rates are about as high as in the U.S. Assuming the trends towards gender equity, and while women's higher labour force attachment and higher divorce rates continue in other countries, the Swedish context can be seen as describing these aspects of the future in other developed countries.

Results from earlier studies from developed countries vary in a number of aspects, and the way and extent to which the wife's income is related to the divorce risk is not clear. On the one hand, and given the more egalitarian gender views today, equal incomes would not have a destabilizing effect on marriage. On the other hand, it would be easier for either of the spouses to exit an unhappy marriage if one spouse did not depend on the income of the other. In addition, one needs to consider the level of the combined income of both spouses. Research has found that wives' contributions to family income lowered the risk of divorce by alleviating economic distress (Conger, et al., 1990). Hence, in what way and to what extent does the wife's income, and in particular its ratio to the income of the husband, influence the risk of divorce? Educational attainment could also mediate the effect of wives' relative income on divorce because education could be a proxy variable for the earning potential. The existing studies ignore these elements. In this paper, these questions are addressed by applying them to Sweden, one of the countries with the least traditional system of gender relations and ideology.

In our empirical investigation, a particularly large nation-wide individual-level data set is used constructed by linking data from different administrative registers, which alleviates some concerns typical to survey data, such as sample representivity, statistical power, and reliability of self-reported income.

\section{Background and Hypotheses}

\section{Wife's Economic Independence}

The relationship between increasing women's earnings and rising divorce rates has been often explained by the independence effect: when a woman makes an income that allows her to be financially self-supporting, she would find it relatively easy to exit a marriage should she wish to do so. More generally, if a wife earns more money than her husband does, her gains are less from marriage than a wife's whose earnings are lower (Becker, Lands \& Michael, 1977). This effect rests on the assumption from economic theory that the division of breadwinning and domestic work along gender lines is beneficial to the family, and the mutual dependence of spouses is a major gain to being married (Becker, 1981). Sociological theory of the family has also emphasized the specialized 
division of labour as a functional necessity for the institution of marriage (Parsons, 1949). Departure from this model would reduce benefits from marriage and increase the likelihood of divorce. A frequently presented argument is that a higher income of the wife would destabilize the relationship between her and her husband (Ross \& Sawhill, 1975; Moore \& Waite, 1981; Spitze \& South, 1985).

These theoretical approaches are anchored on the sole-earner family model that was prevalent in the 1950s and 1960s. This context no longer dominates in developed countries, such as the U.S., and is quite distant from the context of our empirical investigation, as shown in Section 2.5. Oppenheimer (1997) argues that, theoretically, the clear division of household work along gender lines is no longer the best rational choice in a contemporary society because of the risks that a nuclear family entails if one of its adult members cannot perform his or her function. She points out that support for the independence effect hypothesis was found only in cross-sectional aggregate-level studies that use data from the 1950s and 1960s, i.e. when the different family and labour market roles of men and women were still a dominating social norm. In this connection, the opposite direction of causality, namely, that women increase labour force attachment in response to marital discord, may have an important role. Based on analyses of panel data in the U.S., Rogers (1999) suggests this as being the dominating causal link between women's income and divorce risk.

Oppenheimer (1997) also distinguished the independence effect from the income effect. Focusing only on the ratio of a wife's income to that of her husband, and ignoring its interaction with the absolute income level of the family, "tends to distract attention from the underlying causes of these ratios and their structure determinants" (Oppenheimer, 1997, p. 431). The independence effect hypothesis predicts a linear increase in divorce risk by the wife's income, measured either in absolute or relative terms. Sørensen \& McLanahan (1987) argue that relative income of wives is a valid measure of economic dependency at all income levels, including that of families with high incomes. Here, the wife may be able to earn money at a level that would allow her to support herself financially. Even then, if the husband has higher earnings, she would be dependent on him for maintaining her current living standard and possibly her social status.

Nevertheless, total income of couples could be an important factor to mediate the effect of relative income of wives on divorce. In low-income families, higher income of wives helps to reduce the family's economic hardship and does not be a disruptive factor for marital stability. In those families, a higher share of wives' income does not mean that wives are economically independent from their husbands, either. White \& Rogers (2000) conclude that evidence on the effect of the success of wives as co-providers on divorce risk is inconsistent, whereas problems arise when wives' earnings are substantially greater than their husbands. 
Educational attainment could serve as a measure of earning ability, measure of skills of bargaining and solving disputation within marriages. Although education correlates positively with earnings, women with higher education have been found to have lower divorce risks (e.g., Ono, 1998; South, 2001). This negative effect of education on divorce casts has been linked to greater (inter)personal skills among the better educated (Ono, 1998). Interestingly, Kalmijn, de Graaf \& Portman (2004) find a positive effect of wife's education on divorce in the Netherlands. This warrants controlling for the effect of education level of both partners and checking its interactions with the income measure in our analysis.

Based on these considerations, the following hypotheses are proposed:

Hypothesis 1 - independence effect: divorce risk increases in an approximately linear relationship with the wife's relative income.

Hypothesis 1a - mediating effect of total income: at low levels of total income, the independence effect does not hold.

\section{Equal Dependence of Spouses}

Several recent studies that use individual level data and advanced statistical methods have challenged the understanding of a linear relationship between the wife's relative income and divorce risk. Nock (2001) has introduced the concept of marriages of equally dependent spouses (MEDS), as unions in which either of the spouses generates between 40 to $60 \%$ of the couple's total income. He showed that in such marriages, the wife's commitment to the marriage is lower than in other marriages. The husband's commitment, by contrast, does not depend on earnings. The wife's commitment also decreased with the amount of time she spent in paid work. In sum, Nock (2001) argues that MEDS lead to higher divorce risks mainly because the wife gains less from the partnership, and because the threshold to leave the marriage is relatively low. These arguments are in similar vein to those concerning the independence effect. However, in addition to the economic independence thesis, he argues that the relationship quality suffers because of the wife's perception that the household tasks are unfairly distributed to her disadvantage. This is because men's attitudes to housework have not matched the increase in women's labour-force participation. This is to say, it may be only the wife who perceives the relationship quality to be suffering. As Sayer \& Bianchi (2000) have shown, the wife's satisfaction and happiness with the relationship is a predictor of its divorce, whereas this does not apply to the husband. These arguments lead us to propose:

Hypothesis 2 - effect of equal dependency: the divorce rates in which either of the spouses generates between 40 to $60 \%$ of 
Guiping Liu and Andres Vikat

the total income are higher than that of couples where the wife earns less than $40 \%$ of the income.

Heckert, Nowak \& Snyder (1998) found an inverted U-shape relationship between the relative income of wives and divorce risk of the family: traditional couples where the wife depended financially on her husband and the "reverse traditional couples" that the wife's income accounted for $75 \%$ or more of the total incomes, were less likely to divorce.

Hypothesis $2 \mathrm{a}$ - reverse traditional couples: at the level of above $75 \%$ of the couple's earnings, the wife's relative earnings do not increase the divorce risk.

\section{Expectations on Gender Relations}

Many analysts argue that gender ideology mediates the effect of women's relative income on divorce risks (Greenstein, 1995; Oppenheimer, 1997; Sayer \& Bianchi, 2000; Brennan et al., 2001). They claim that the independence effect hypothesis is based on traditional gender ideology: when men are mainly engaged in labour-market activity and women are not, women are economically dependent on men. Woman's employment thus does not meet the traditional norm and therefore destabilizes the marriage, so the argument goes. However, in a modern western society, the labour market roles of both sexes have become increasingly similar. This is reflected in a gender ideology that has become increasingly egalitarian. In this context, then, equal income of both partners stabilizes rather than destabilizes marriage. Ono (1998) and Rogers (2004) suggest a U-shape relationship in which the risk of divorce is lowest when wife and husband contribute a similar share of total family income. As Sayer \& Bianchi (2000) have shown, the wife's satisfaction and happiness with the relationship is a predictor of its divorce, whereas this does not apply to the husband.

An alternative theory explaining the effect of relative income of wives on marital instability is the bargaining model (Nash 1950; Lundberg \& Pollak 1996). Wives with higher income have bargaining power with their husbands. They have higher expectations of greater equity in marital power and division of household work (Risman \& Johnson-Sumerford, 1998). The theory explains that wives were more likely to dissolve their marriages if they could not reach a point as a result of bargaining with their husbands with lower earning ability.

Hypothesis 3 - effect of egalitarian gender attitudes: couples where each spouse contributes about $40-60 \%$ of the total income have the economic power structure that conforms to the egalitarian gender ideology that prevails in Sweden. This leads to lower divorce risks of such couples. 
Does Divorce Risk in Sweden depend on Spouse's Relative Income?

A Study of Marriages from 1981 to 1998

\section{Income Effect}

The income effect implies when a higher total income of the family improves the quality of family life and thereby enhances marital stability. From this perspective, higher income of wives should have a stabilizing influence on the marriage as it increases the total family income. On the other hand, a husband's poor performance in the labour market increases divorce risk not only through the economic difficulties this may cause to the family, but also through the strain caused by not fulfilling the wife's expectations. So far, only a few studies have distinguished between the independence and income effect. They found the income effect to be weak or non-existent (Greenstein, 1990, 1995).

Hypothesis 4 - income effect: a higher combined income earned from employment improves the couple's quality of life and in this way enhances marriage stability. It follows that divorce risks decrease with the couple's total income rising.

\section{Swedish Context}

Sweden is well known for its high female participation rate in the labour force. There has been a political commitment to sustaining equality between men and women in family and society (Hirdman, 1998). During the 1960s and 1970s, a series of social policies were introduced that aimed at ensuring equal status between the sexes. In 1974, a parental leave program was established according to which employed women/men with young children received $90 \%$ of their income if they stayed at home during the first six months of the child's life (this was later extended to 12 months). Full job security for that period was provided. The entitlement period was later prolonged to 15 months, of which at least one month has to be taken by the other parent (see Sundström \& Duvander, 1999). The benefit level stood at $80 \%$ of the claimant's average earnings during the 240 days preceding birth. More than half of the fathers take at least some parental leave after the birth of their first child and $11 \%$ take three or more months (Oláh, 2001). These policies stimulated the rate of women's labour force participation in Sweden to reach a very high level: it increased from 53\% in 1963 to $86 \%$ in 1990 (Hirdman, 1998), in 1991 the level stood at 78\%, and in 2000 at $71 \%$ (European Commission, 2002). Female earnings, relative to men's, increased too (Henz \& Sundström, 2001).

Sweden is also well known as the forerunner of many of the recent demographic trends that Europe has been witnessing, such as an increase in consensual union formation and non-marital childbearing. Less than $10 \%$ of all unions in Sweden start as non-marital unions (Statistics Sweden, 1995) and 55\% of all children are born out of wedlock (Council of Europe, 2003). About half of all Swedish women and nearly as much of all men have a non-marital partnership at age 26 
Guiping Liu and Andres Vikat

(Bernhardt, 2002). The 'no fault' rule applied in legal proceedings makes divorce relatively easy to obtain. The rise of divorce rates throughout Europe accelerated in the second half of the 1960s. In Sweden, this increase has continued over recent decades. The 1990s level of the total divorce rate is among the highest in Europe: it ranges from 0.44 to 0.55 (Council of Europe, 2003). Sweden has one of the highest union disruption levels in Europe (Andersson, 2003) considering the high prevalence of non-marital unions, which are after all less stable than marriages.

Studies of Swedish divorce trends have highlighted that in the 1980s and 1990s divorce risks increased in particular among couples with children. At the same time, the number of childless couples and unions with pre-marital children increased - both of these groups have displayed a higher than average risk (Andersson, 1995). Andersson (1997) demonstrates that Swedish divorce risks vary by parity and the age of the youngest child. Liu (2002) shows that stepchildren have a detrimental effect on marital stability. The results of both studies were considered when selecting and defining the control variables for the regression models in our paper.

Jalovaara (2001, 2003) analyzes the association between socioeconomic positions and divorce risk in Finland, a country adjacent to Sweden that shares many of the features in social structure, the Nordic model of the welfare state, and cultural aspects with its neighbour. Both the high level of female labour force participation and the egalitarian gender ideology particularly enhance the comparability of results from these two countries. Furthermore, the system of registers in both countries allows analyzing the effect of socioeconomic characteristics of both spouses on divorce. The Finnish studies confirmed the relationship between the socioeconomic status and divorce as an inverse one. In a study on the interactive effects of spouses' socioeconomic positions, Jalovaara (2003) found that couples where the wife had a higher income than her husband were somewhat more prone to divorce.

\section{Data and Method}

\section{Data}

We use a set of Swedish register data that contains records of all women born in Sweden between 1945 and 1981. Statistics Sweden prepared it by linking individual-level information on demographic, social, and economic variables from different registers. In our study, women who married between January 1981 and December 1998 were included, and the divorce risks of these marriages were analyzed. Our analysis is limited to marriages between spouses born in Sweden to eliminate any influence that the cultural origin or cultural 
heterogeneity of spouses would have on our results. Furthermore, both early (before age 20) and late first marriages (after age 35) were excluded to avoid distortion of our results by sub-groups whose divorce risk is known to be substantially different. In all, 446,145 marriages are included in this analysis, 77,593 of which ended in divorce during the observation period. The follow-up covers 3,892,005 marriage-years.

The social and economic variables pertain either to the status at the end of a calendar year or income received during the year. Demographic events marriage, divorce, and birth of children - are recorded to the precision of a month. The individual records of husbands are linked to the records of their wives. This enables us to study the association of the combined socio-economic characteristics of both spouses with marital stability.

\section{Study Variables}

Our dependent variable is the event of divorce measured at a month's precision. The explanatory variables used to test our hypotheses are relative income, total income, wife's level of education, and relative level of education.

For both income variables, the total income from employment and social security benefits (unemployment insurance, parental leave, student allowances) are used in this study. The reason is that in Sweden, transfer money is an important part of couples' income. Take parental leave benefit as an example. Either spouse on parental leave receives $80 \%$ of her or his salary 240 days before the new baby is born. She or he can receive this amount of money for 15 months in total. Since this information is applied to explain divorce risks, we specify our models so that income received during year $t$ is used to explain the divorce risks during year $t+1$. Relative income is defined as the wife's contribution in percentage to the total income of both spouses. The variable is represented in five categories, using cut-points at every 20th percentile (Table 1). Total income is the sum of both spouses' income adjusted for inflation and expressed in Swedish crowns (SEK) of the 1998 value. This variable is listed in four categories that we obtained by using quartile cut-off points in the distribution of married couples by total income. Both of these variables are timevarying covariates, the values of which are updated at the end of each calendar year. 
Does Divorce Risk in Sweden depend on Spouses' Relative Income?

A Study of Marriages from 1981 to 1998

Table 1

Number of Divorces and Couple-Months Observed in Marriages

by the Study Variables for Sweden: 1981-1998

\begin{tabular}{|c|c|c|c|c|c|}
\hline \multirow{2}{*}{ Variable name } & \multirow{2}{*}{ Category } & \multicolumn{2}{|c|}{ Divorces } & \multicolumn{2}{|c|}{$\begin{array}{c}\text { Couple-months observed in } \\
\text { marriages }\end{array}$} \\
\hline & & Number & $\%$ & Number & $\%$ \\
\hline Wife's Share in & $0-20 \%$ & 4,046 & 6 & 253,928 & 7 \\
\hline \multirow[t]{4}{*}{ Couple's Total Income } & $20-40 \%$ & 23,452 & 35 & $1,329,407$ & 38 \\
\hline & $40-60 \%$ & 32,931 & 49 & $1,682,854$ & 48 \\
\hline & $60-80 \%$ & 4,779 & 7 & 184,292 & 5 \\
\hline & $80 \%+$ & 2,265 & 3 & 67,297 & 2 \\
\hline Couple's Total Income & $0-25.2$ & 22,455 & 33 & 985,049 & 28 \\
\hline \multirow{3}{*}{$(10,000$ SEK in 1998 value $)$} & $25.2-40.3$ & 28,865 & 43 & $1,498,054$ & 43 \\
\hline & $40.3-55.5$ & 13,026 & 19 & 800,890 & 23 \\
\hline & $>55.5$ & 3,127 & 5 & 233,786 & 7 \\
\hline \multirow[t]{4}{*}{ Husband's Education Level } & pre-gymnasium & 14,403 & 21 & 617,654 & 18 \\
\hline & gymnasium & 35,772 & 53 & $2,040,000$ & 58 \\
\hline & post-gymnasium & 5,057 & 8 & 497,415 & 14 \\
\hline & unknown & 12,241 & 18 & 362,710 & 10 \\
\hline \multirow[t]{4}{*}{ Wife's Education Level } & pre-gymnasium & 14,672 & 22 & 457,454 & 13 \\
\hline & gymnasium & 46,140 & 68 & $2,545,498$ & 72 \\
\hline & post-gymnasium & 5,057 & 7 & 436,761 & 12 \\
\hline & unknown & 1,604 & 2 & 78,066 & 2 \\
\hline Couple's Relative & husband higher than the wife & 10,226 & 15 & 505,113 & 14 \\
\hline \multirow{3}{*}{ Education Level } & equal & 32,772 & 49 & $1,986,376$ & 56 \\
\hline & wife higher than the husband & 11,025 & 16 & 598,241 & 17 \\
\hline & $\begin{array}{l}\text { either education level } \\
\text { unknown }\end{array}$ & 13,450 & 20 & 428,051 & 12 \\
\hline \multirow[t]{6}{*}{ Couple's Age Difference } & $\begin{array}{l}\text { husband } 6 \text { or more years } \\
\text { older }\end{array}$ & 14,524 & 22 & 579,379 & 16 \\
\hline & husband 3-5 years older & 16,649 & 25 & 890,912 & 25 \\
\hline & husband $1-2$ years older & 16,098 & 24 & 946,025 & 27 \\
\hline & $\begin{array}{l}\text { age difference smaller than } 1 \\
\text { year }\end{array}$ & 11,819 & 18 & 717,782 & 20 \\
\hline & wife $1-2$ years older & 5,073 & 8 & 253,519 & 7 \\
\hline & wife 3 or more years older & 3,310 & 5 & 130,163 & 4 \\
\hline \multirow[t]{3}{*}{ Wife's Age at Marriage } & $20-23$ & 21,328 & 32 & 766,177 & 22 \\
\hline & $24-25$ & 29,525 & 44 & $1,638,627$ & 47 \\
\hline & $29-35$ & 16,620 & 25 & $1,112,975$ & 32 \\
\hline Number of Wife's & 0 & 57,942 & 86 & $3,289,566$ & 94 \\
\hline Children from Previous & 1 & 7,177 & 11 & 180,797 & 5 \\
\hline Partnerships & $2+$ & 2,354 & 3 & 47,415 & 1 \\
\hline Number of Husband's & 0 & 57,153 & 85 & $3,206,953$ & 91 \\
\hline Children from Previous & 1 & 6,103 & 9 & 189,794 & 5 \\
\hline Partnerships & $2+$ & 4,217 & 6 & 121,032 & 3 \\
\hline Age of Youngest & no child & 15,575 & 23 & 460,102 & 13 \\
\hline \multirow{6}{*}{$\begin{array}{l}\text { Age or Youngest } \\
\text { Shared Child }\end{array}$} & woman pregnant & 319 & 0 & 276,114 & 8 \\
\hline & under 1 year & 885 & 1 & 503,797 & 14 \\
\hline & $1-2$ years & 11,776 & 17 & 822,153 & 23 \\
\hline & $3-5$ years & 21,846 & 32 & 733,619 & 21 \\
\hline & $6-8$ years & 10,284 & 15 & 404,091 & 11 \\
\hline & 9 years or older & 6,787 & 10 & 317,903 & 9 \\
\hline Husband's & first & 61,550 & 91 & $3,317,934$ & 94 \\
\hline Order of Marriage & second or higher & 5,923 & 9 & 199,846 & 6 \\
\hline
\end{tabular}


Age difference is calculated using the spouses' exact dates of birth. Education attainment refers to the highest level of education obtained. It is defined as a time-varying covariate that is updated each time the person completes a higher level of education than he/she previously had. In this study, the education level is categorized as (a) pre-gymnasium, including pre-school education and nine years of compulsory basic education; (b) gymnasium, including upper secondary school (usually three years) and adult education; (c) post-gymnasium, including college and university. The relative level of education reflects the ratio of the spouses' education level according to these three categories. Hoem (1997a) has shown the emergence and increase of a negative correlation between a wife's education level and divorce risk in Sweden in the 1980s; a negative correlation has also been found in the United States (Lillard \& Waite, 1993).

In addition, we use in our models a number of control variables that are known to influence divorce risk. Wife's age at marriage is one of them: it is found to have a powerful impact on marital breakdown, even more so than socioeconomic status variables such as social class (Murphy, 1985).

Many studies, including those using Swedish data (Andersson, 1995, 1997; Hoem, 1997b), have shown that divorce risk varies by shared children, childless couples usually having a higher divorce risk than couples with children, and couples with small children or when the wife is pregnant having the lowest divorce risk. For our analysis, the variable age of youngest shared child is defined as a time-varying covariate that has the following categories: no shared children, wife currently pregnant, youngest child younger than one year, age of youngest child from one to two, three to five, six to eight, and nine or more years.

It has been shown by Becker, Lands and Michael (1977) and Cherlin (1978) for the United States and by Hoem (1997a) and Liu (2002) for Sweden that, in addition to the variation of the divorce risk by the couple's shared children, the presence of premarital children increases the risk of divorce. Based on these results, separate control variables are included for the number of the wife's children from previous unions and husband's children from previous unions. These variables include all children before the current marriage whose other parent is not the current husband or wife. Marriages of second and of higher order are more prone to dissolve than first marriages, which have also been attributed to the notion that relationships in stepfamilies generally are less harmonious and gratifying (see Furstenberg, 1990). This is because family norms are usually ambiguous and bonds between stepparents and their children are weaker and sometimes fraught with conflict. Erlangsen and Andersson (2001) have recently shown that divorce risks in Sweden also rise with the order of marriage. The order of the current marriage is included to control for this. 
Guiping Liu and Andres Vikat

\section{Statistical Procedure}

Estimated hazard regression models of the divorce risks are defined as:

$$
\ln \mu_{i}(t)=y(t)+\sum_{j} \alpha_{j} x_{i j}+\sum_{l} \beta_{l} w_{i l}(t)
$$

where $t$ denotes marriage duration, $\mu_{i}(t)$ represents the intensity of divorce at duration $t$ for individual $i, y(t)$ is the logarithm of the baseline intensity, $x_{i j}$ stands for fixed covariates, $\alpha_{j}$ for coefficients for fixed covariates, $w_{i j}$ for time-varying covariates, and $\beta_{i}$ for coefficients of time-varying covariates.

The baseline time parameter of the divorce risk is the duration of marriage, which is specified as a linear spline with nodes at 1,2,3,5, 7, and 11 years, until observations are censored at 15 years of marriage. Observations are also censored at the emigration or death of either spouse and at the end of the year 1998, whichever occurs first. The regression coefficients of spline functions spline gradients - express the change in the logarithm of the divorce risk between two consecutive nodes per unit of measurement.

Due to the large size of the data set, statistical significance is not used as a criterion for model building or for the assessment of the results: even very small coefficients render statistical significance. Our selection of control variables into the models is inspired by results of earlier studies. The rare occasions where a coefficient is not significant according to the likelihood ratio test at the fivepercent level are marked in the tables.

Results are reported from the models listed below:

Model $1=$ control variables + total income + relative income

Model 1a $=$ Model $1+$ total income $*$ relative income

Model 2 = Model $1+$ husband's education level + wife's education level

Model 2a $=$ Model $2+$ total income $*$ wife's education level

Model $3=$ Model $2+$ relative level of education 
$a M L$ software was used to fit the models (Lillard \& Panis, 2000). Model 1 tests the independence effect and the income effect simultaneously. Both spouses' levels of education are added in Model 2 and spouses' relative education in Model 3. The interactions of the wife's relative income with total income in Model 1a, and the interactions of the wife's relative income with the wife's education level in Model 2a were also investigated.

\section{Results}

\section{Control Variables}

The relative divorce risks by the control variables change very little from one model to another, and those obtained from Model 1 reflect well their effects (Table 2). These effects are consistent with the results from earlier studies that have motivated us to control for them. Divorce risks decreased with the wife's age at marriage linearly at about $11 \%$ per year.

The more children the wife or the husband had from a previous relationship, the more likely the marriage was to dissolve. Apparently, the children from wife's pre-union have a larger disruptive effect than those children from the husband's pre-union. Having a shared child is a sign of commitment to the relationship (Thomson et al., 2002), and this is clearly reflected in the lower divorce risk of couples with children as compared to childless couples. The risk of divorce was considerably higher if the wife had been married before, whereas such experience of the husband did not influence the divorce risk notably.

A large age difference between the spouses increased their divorce risk. When the husband was one or two years older than the wife - which is the most common age configuration - the couple faced the lowest divorce risk. It increased the more a couple deviated from this. The increase in the divorce risk was notably larger if the husband was younger than the wife as compared to the opposite situation.

\section{Spouses' Income and Education}

We first examine the main effects of the explanatory variables estimated in Model 1, which includes the demographic control variables and the income variables (Table 3). There was a clear linear pattern in the effect of a wife's relative income: the higher the wife's share in the couple's income, the higher the divorce risk. When the wife contributed $80 \%$ or more to the total income, the divorce risk was twice as high as when she contributed less than 20\%; other categories by relative income faced a divorce risk between those two extremes. These estimates are controlled for the couple's total income. The effect of the 
Table 2

Relative Divorce Risk by Control Variables for Sweden: 1981-1998

\begin{tabular}{|c|c|c|c|}
\hline Variable & Category & $\begin{array}{c}\text { Relative } \\
\text { Risk } \\
\end{array}$ & $\begin{array}{c}\text { Spline } \\
\text { Gradient } \\
\end{array}$ \\
\hline Marriage Duration, Exact Years & $\begin{array}{l}0-1 \\
1-2 \\
2-3 \\
3-5 \\
5-7 \\
7-11 \\
11+\end{array}$ & & $\begin{array}{c}2.9981 \\
0.6164 \\
0.1899 \\
-0.0285 \\
-0.0721 \\
-0.0728 \\
-0.0611\end{array}$ \\
\hline Wife's Age at Marriage & & & -0.1128 \\
\hline Order of Marriage, Wife & $\begin{array}{l}1^{\text {st }} \\
2^{\text {nd }}+\end{array}$ & $\begin{array}{l}1.00 \\
1.43\end{array}$ & \\
\hline Order of Marriage, Husband & $\begin{array}{l}1^{\text {st }} \\
2^{\text {nd }}+\end{array}$ & $\begin{array}{l}1.00 \\
1.02\end{array}$ & \\
\hline $\begin{array}{l}\text { Number of Wife's Children } \\
\text { from Previous Partnerships }\end{array}$ & $\begin{array}{l}0 \\
1 \\
2+\end{array}$ & $\begin{array}{l}1.00 \\
1.98 \\
2.31\end{array}$ & \\
\hline $\begin{array}{l}\text { Number of Husband's Children } \\
\text { from Previous Partnerships }\end{array}$ & $\begin{array}{l}0 \\
1 \\
2+\end{array}$ & $\begin{array}{l}1.00 \\
1.60 \\
1.59\end{array}$ & \\
\hline Number of Shared Children & $\begin{array}{l}0 \\
1 \\
2 \\
3 \\
4+\end{array}$ & $\begin{array}{l}1.58 \\
1.29 \\
1.00 \\
0.98 \\
1.21\end{array}$ & \\
\hline $\begin{array}{l}\text { Age of Youngest Shared Child, } \\
\text { Exact Years }\end{array}$ & $\begin{array}{l}\text { wife pregnant } \\
0-1 \\
1-3 \\
3-6 \\
6-9 \\
9+\end{array}$ & $\begin{array}{l}0.28 \\
0.17 \\
0.43 \\
1.00 \\
1.03 \\
1.06\end{array}$ & \\
\hline $\begin{array}{r}\text { Intercep } \\
\exp (\text { Intercept }\end{array}$ & & $\begin{array}{c}-4.3522 \\
0.0129\end{array}$ & \\
\hline
\end{tabular}

Notes: Relative risks not significantly different from the reference category at five percent level are in italics. All other estimates are significant at the five percent level. Estimated from a hazard regression model that includes all these variables, the two income variables, and spouse's age difference (Model 1). 
couple's total income on divorce risk primarily concerned the lower part of the income distribution. Couples in the lowest quartile had the highest divorce risk. In the middle part of the distribution, there was no change, whereas those in the highest quartile had a slightly higher risk.

In Model 2, both the wife's and the husband's level of education were added, both of which showed a strong influence on divorce risk (Table 3). A higher education level of either spouse clearly decreased the divorce risk. A wife's education has a somewhat larger influence, as couples with a wife who had attained higher education were half as likely to divorce as couples where the wife had a low education level. These estimates are controlled for the income variables, but they change very little only when these variables are removed from the model (results not shown). This relationship also holds when relative education level was added to the model. If the wife's education was higher than that of the husband, the couple had a lower divorce risk than other couples. There was no difference between couples of the same education level and couples where the husband's education was higher than that of the wife's. The effect of relative education on divorce risk is by far smaller than that of relative income.

The inclusion of education level in the model did not have any influence on the effect of relative income, but considerably altered that of the couple's total income. After controlling for education level, a $U$ shape relationship appeared with the highest income bracket having the highest divorce risk, and couples between the $25^{\text {th }}$ and $50^{\text {th }}$ percentile the lowest.

The interactions between wife's share of total couple income and total couple income (Figure 1) show that in all three percentiles of couple's income, the higher the wife's share of income, the higher the hazard of divorce, though the rate of change of divorce hazard in the lowest 5\% income percentile looks flat. The interactions between the wife's share of total income and the wife's education level indicates that in all three categories of wives' education levels -low, medium and high, the hazard of divorce increases with her share of the couple income (Figure 2). To save space in this paper, results are not presented in the tables.

\section{Discussion}

Swedish register data used in this analysis has several advantages. Since the data set covers the entire population, there is no need to be concerned with sampling issues and statistical power to support the observed substantive differences. There is also no need to deal with reporting errors that may be encountered in self-reported income data. With the exception of two recent studies from Finland (Jalovaara, 2001, 2003), earlier work on the relationship. 
Guiping Liu and Andres Vikat

Figure 1

Interaction between Wife's Share of Couple Income and Total Couple Income

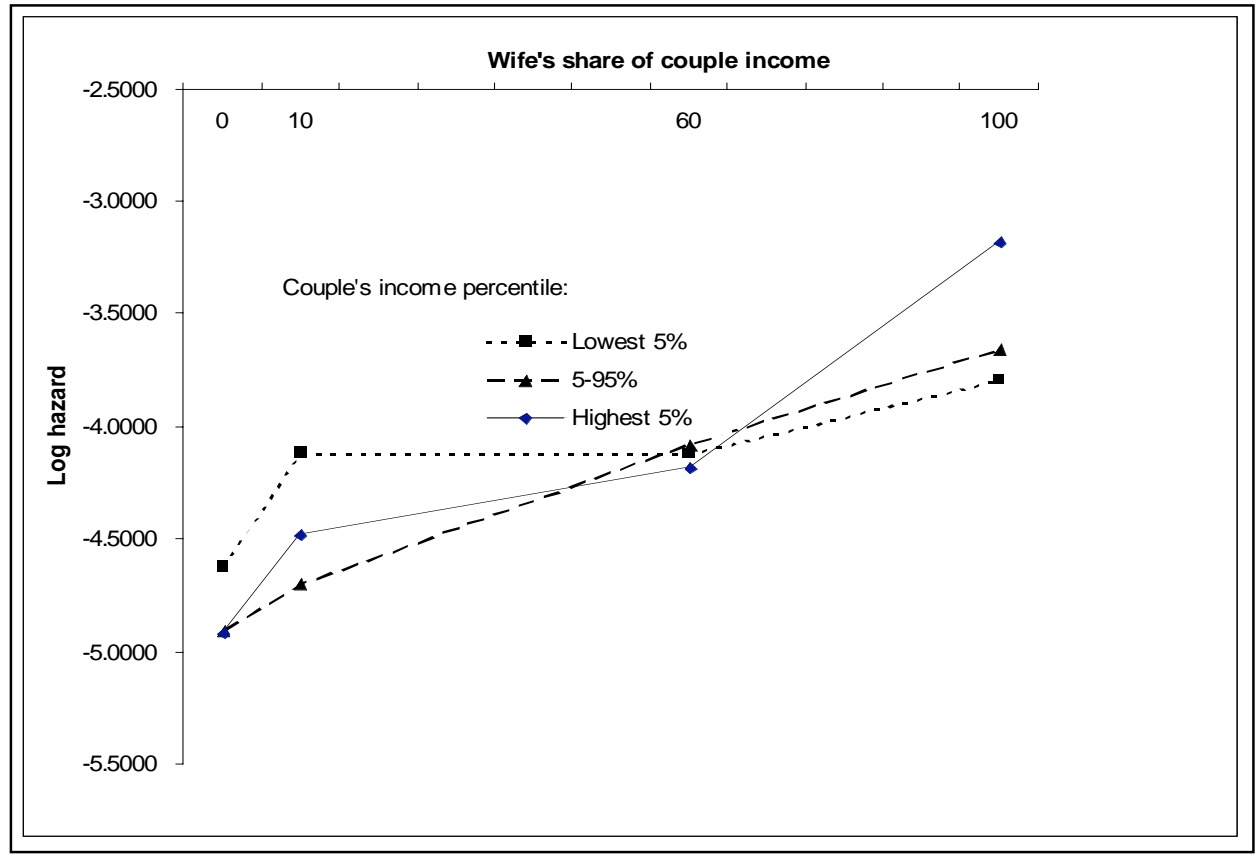


Figure 2

Interaction between Wife's Share of Couple Income and Wife's Educational Level

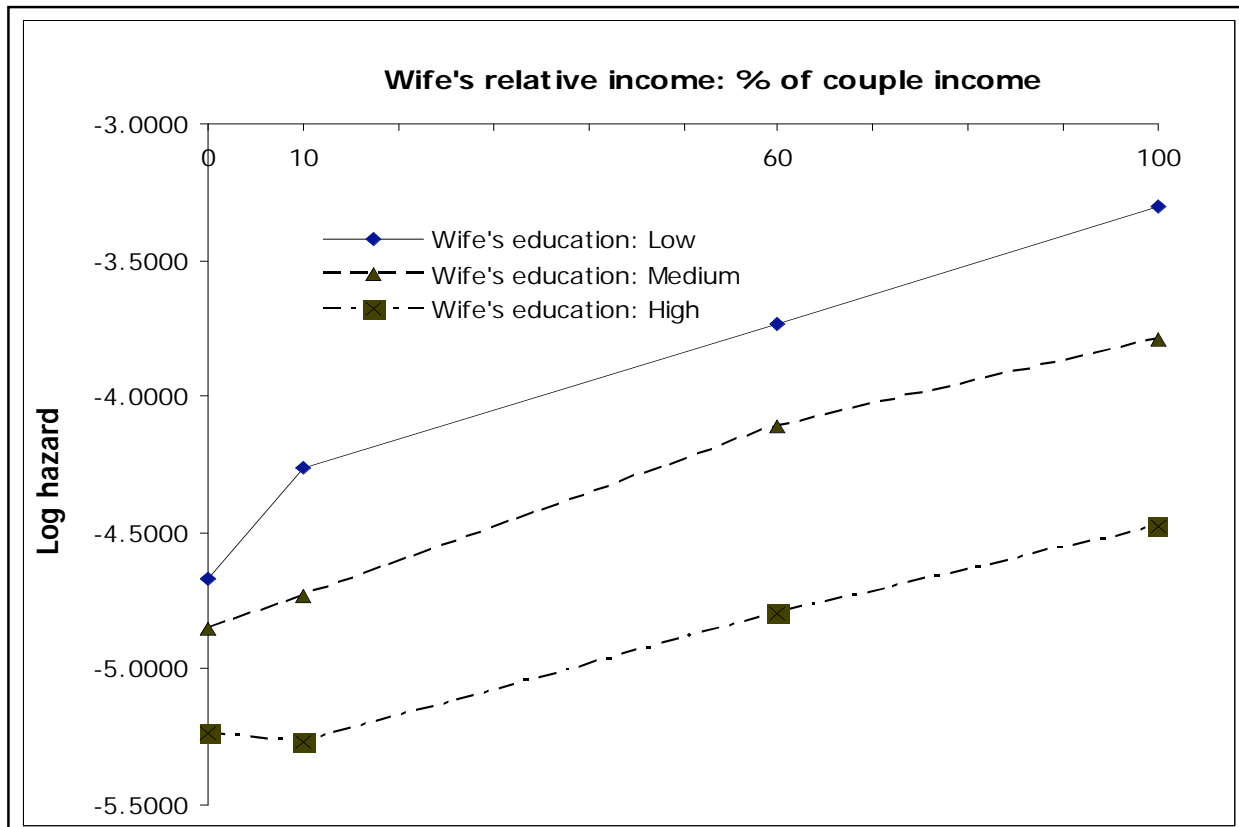


Table 3

Relative Divorce Risk by Explanatory Variables estimated from Hazard Regression Models that also include the control variables presented in Table 1

\begin{tabular}{|c|c|c|c|c|}
\hline Variable & Category & Model 1 & Model 2 & Model 3 \\
\hline Wife's Share in Couple's & $0-20$ & 0.67 & 0.65 & 0.65 \\
\hline \multirow[t]{4}{*}{ Total Income (\%) } & $20-40$ & 0.84 & 0.83 & 0.83 \\
\hline & $40-60$ (ref.) & 1.00 & 1.00 & 1.00 \\
\hline & $60-80$ & 1.27 & 1.30 & 1.31 \\
\hline & $80-100$ & 1.40 & 1.41 & 1.42 \\
\hline \multirow{4}{*}{$\begin{array}{l}\text { Couple's Total Income, } \\
\text { Percentile }\end{array}$} & $0-25$ & 1.16 & 1.12 & 1.12 \\
\hline & $25-50$ (ref.) & 1.00 & 1.00 & 1.00 \\
\hline & $50-75$ & 1.02 & 1.05 & 1.05 \\
\hline & $75-100$ & 1.04 & 1.16 & 1.16 \\
\hline \multirow[t]{6}{*}{ Couple's Age Difference } & husband 6 or more years older & 1.09 & 1.05 & 1.06 \\
\hline & husband 3 to 5 years older & 0.99 & 0.97 & 0.97 \\
\hline & husband 1 to 2 years older & 0.98 & 0.97 & 0.97 \\
\hline & age differene $<=1$ year (ref.) & & 1.00 & 1.00 \\
\hline & wife 1 to 2 years older & & 1.26 & 1.25 \\
\hline & wife 3 or more years older & & 1.62 & 1.62 \\
\hline \multirow{3}{*}{$\begin{array}{l}\text { Husband's Level of } \\
\text { Education }\end{array}$} & pre-gymnasium & & 1.11 & 1.16 \\
\hline & gymnasium (ref.) & & 1.00 & 1.00 \\
\hline & post-gymnasium & & 0.84 & 0.81 \\
\hline \multirow[t]{3}{*}{ Wife's Level of Education } & pre-gymnasium & & 1.46 & 1.42 \\
\hline & gymnasium (ref.) & & 1.00 & 1.00 \\
\hline & post-gymnasium & & 0.83 & 0.81 \\
\hline Couple's Relative & husband's education higher & & & 0.99 \\
\hline \multirow[t]{2}{*}{ Level of Education } & same level of education (ref.) & & & 1.00 \\
\hline & wife's education higher & & & 0.92 \\
\hline
\end{tabular}

Note: Relative risks not significantly different from the reference category at 5\% level are in italics. All other estimates are significant at the 5\% level. 
between individual-level economic variables and divorce risk has been based on sample surveys

Throughout the analyses, support was found for the independence effect hypothesis, as the divorce risk increased linearly with the share of the wife's income to the couple's total income. This result is interpreted to be in line with the dominant arguments in the literature, according to which a higher income lowers the wife's constraint to exit an unhappy marriage. For women whose income is high in both relative and absolute terms, an additional interpretation may be that a high absolute income level grants them greater freedom in pursuing individual life goals, and that they may place high requirements on the qualities of their partner. A couple's non-traditional income ratio may have a negative influence on the quality of the relationship by threatening the traditional division of labour and breadwinner roles if these are valued by at least one of the spouses, usually the husband. The egalitarian value orientations prevailing in Sweden are assumed to reduce the influence of the non-traditional income ratio of spouses on their relationship quality. Against this background, finding such a strong independence effect and no support to the egalitarian gender attitudes hypothesis may be seen as somewhat unexpected. However, results of a recent study from Finland, where the context of gender relations resembles that of Sweden, were also consistent with the independence effect (Jalovaara, 2003).

The direction of the causal link between relationship quality and relative income can also be the opposite one, however. Johnson \& Skinner (1986) and Rogers (1999) show that increases in perceived marital discord are related to increases in wives' income. If this relationship holds in Sweden, it would explain some of the variation in divorce rates by spouses' relative income that is presented.

With register data, it would not be possible to disentangle the relative importance of those interpretations: a self-supporting wife has a lower threshold to exit an unhappy marriage, the unconventional power relations resulting from the wife's higher income decrease the relationship quality, or marital discord stimulating wives to increase their income. It is likely that they all contribute to shaping the observed divorce pattern by spouses' income ratio. The age of the youngest child is used as a control variable in your models because of its high association with divorce risk as indicated in existing literatures. The number of children in the family, however, could be a factor that is related to couples' economic status and plays role in influencing family stability. This study would be more convincing if this issue is taken into consideration.

Our study lends some support to the income effect: couples with low income had a higher divorce risk. In the higher income brackets, divorce rather increased with income. Like previous studies that have aimed at distinguishing between the income and the independence effect (Greenstein, 1990, 1995), our 
Guiping Liu and Andres Vikat

finding is inconclusive pointing at the existence of this effect only in a part of the income distribution.

Our hypotheses about equally dependent spouses and egalitarian gender attitudes focused on couples where each partner contributed 40-60\% of the income. This group hardly deviated from the overall pattern of a linear relationship between the wife's relative income and divorce risk. The hypothesis on equally dependent spouses was supported to the extent that it compares this group to the couples with traditional income configuration. However, the further linear increase of divorce risk among the reverse traditional couples where the wife is the main earner of family incomes does not distinguish the group of equal earners within the overall linear relationship between the wife's relative income and divorce risk. Correspondingly, the hypothesis on reverse traditional couples did not find support either.

Our study highlights that couples where the wife earns more than the husband have a relatively high divorce risk not only in a traditional set up but also in a society that is organized on the principles of gender equality and with dominant egalitarian gender views.

\section{Acknowledgements:}

We would like to thank Gunnar Andersson, Jan M. Hoem, and Ann E. Biddlecom for their comments and suggestions on earlier versions of this paper. We also extend our gratitude to Statistics Sweden for granting access to the register data set, Jonathan MacGill for his help in data processing, and Susann

Backer and Rachel Peterson for language editing. Guiping Liu bears the responsibility for any possible error in this article.

\section{References:}

Andersson, G. 1995. "Divorce-risk trends in Sweden 1971-1993,” European Journal of Population, 11(4): 293-311.

Andersson, G. 1997. "The impact of children on divorce risks of Swedish women," European Journal of Population, 13(2): 109-145.

Andersson, G. 2003. Dissolution of unions in Europe: A comparative overview. MPIDR Working Paper WP-2003-004. http://www.demogr.mpg.de/Papers/Working/WP-2003-004.pdf 
Does Divorce Risk in Sweden depend on Spouse's Relative Income?

A Study of Marriages from 1981 to 1998

Becker, G. S. 1981. A Treatise on the Family. Cambridge, MA: Harvard University Press.

Becker, G. S., Lands, E. M. \& Michael, R. T. 1977. "An economic analysis of marital instability," The Journal of Political Economy, 85(6): 11411188 .

Bernhardt, E. 2002. Cohabitation and marriage among young adults in Sweden: Attitudes, expectations and plans. Pp. 157-170 in J. Carling (Ed.), Nordic Demography: Trends and Differentials. Scandinavian Population Studies, Vol. 13. Oslo: Unipub/ Nordic Demographic Society.

Brennan, R. T., Chait Barnett, R. \& Gareis, K. C. 2001. "When she earns more than he does: a longitudinal study of dual-earner couples," Journal of Marriage and the Family, 63: 168-182.

Brines, J. \& Joyner, K. 1999. “The ties that bind: Principles of cohesion in cohabitation and marriage," American Sociological Review, 64 (3): 333-355.

Cherlin, A. 1978. "Remarriage as an incomplete institution," American Journal of Sociology, 84(3): 634-650.

Conger, R. D., Elder, Jr., G. H., Lorenz, F. O., Conger, K. J., Simons, R. L., Whitbeck, Les B., Huck, S., Melby, J.N. 1990. "Linking economic hardship to marital quality and insatbility," Journal of Marriage and the Family, 52/(3): 643-656.

Council of Europe. 2003. Recent demographic developments in Europe: 2003. Strasbourg: Council of Europe.

D’Amico, R. 1983. "Status maintenance or status competition? --Wife's relative wages as a determinant of labor supply and marital instability," Social Forces, 61 (4): 1186-1205.

Erlangsen, A. \& Andersson, G. 2001. The impact of children on divorce risks of first and later marriages. MPIDR Working Paper: WP-2001-033. http://www.demogr.mpg.de/Papers/Working/WP-2001-033.pdf

European Commission. 2002. Statistics on gender issues. http://europa.eu.int/comm/employment_social/equ_opp/statistics_en.ht ml\#nat 
Guiping Liu and Andres Vikat

Furstenberg Jr., F. F. 1990. "Divorce and the American Family," Annual Review of Sociology, 16: 379-403.

Greenstein, T. N. 1990. "Marital disruption and the employment of married women," Journal of Mariage and the Family, 52(3): 657-676.

Greenstein, T. N. 1995. "Gender ideology, marital disruption, and the employment of married women," Journal of Marriage and the Family, 57 (1): 31-42.

Heckert, D. A., Nowak, T. C. \& Snyder, K. A. 1998. "The impact of husbands' and wives's relative earnings on marital distribution," Journal of Marriage and the Family, 60: 690-703.

Henz, U. \& Sundström, M. 2001. "Partner choice and women's paid work in Sweden. The role of earnings," European Sociological Review, 17(3): 295-316.

Hirdman, Y. 1998. State policy \& gender contracts: the Swedish expeience. Pp. 36-46 in E. Drew, R. Emerk \& E. Mahon (Eds.). Women, Work and the Family in Europe. Routledge: London.

Hoem, J. M. 1997a. "Educational gradients in divorce risks in Sweden in recent decades," Population Studies, 51: 19-27.

Hoem, J. M. 1997b. The impact of the first child on family stability. Stockholm Research Reports in Demography, No. 119. Stockholm University. http://www.suda.su.se/SRRD/srrd119.doc

Jalovaara, M. 2001. "Socio-economic status and divorce in first marriages in Finland 1991-93," Population Studies, 55: 119-133.

Jalovaara, M. 2003. "The joint effects of marriage partners' socioeconomic positions on the risk of divorce," Demography, 40(1): 67-81.

Johnson, W. \& Skinner, J. 1986. "Labor supply and marital separation," American Economic Review, 76(3): 455-469.

Kalmijn, M., de Graaf, P.M., Portman, A.-R. 2004. "Interactions between cultural and economic determinants of divorce in The Netherlands," Journal of Marriage and the Family, 66: 75-89. 
Does Divorce Risk in Sweden depend on Spouse's Relative Income?

A Study of Marriages from 1981 to 1998

Lillard, L. A. \& Panis, Constantijn W. A. 2000. aML multilevel multiprocess statistical software, release 1.0 p. 41. Los Angeles, California: EconWare.

Lillard, L. A. \& Waite, L. J. 1993. "A joint model of marital childbearing and marital disruption," Demography, 30(4): 653-681.

Liu, G. 2002. "How premarital children and childbearing in current marriage influence divorce of Swedish women in their first marriages,"

Demographic Research [online] 7(10), 389-406. http://www.demographic-research.org/

Lundberg, S. \& Pollak, R.A. 1996. "Bargaining and distribution in marriage," The Journal of Economic Perpectives, 10 (4): 139-158.

Moore K. A. \& Waite L. J. 1981. "Marital dissolution, early motherhood and early marriage," Social Forces, 60(1): 20-40.

Murphy, M. J.1985. "Demographic and socio-economic influences on recent British marital breakdown patterns," Population Studies, 39(3): 441460.

Nash, Jr., J. F. 1950. “The bargaining problmes,” Econometrica, 18/(2):155162.

Nock, S. L. 2001. "The marriages of equally dependent spouses," Journal of Family Issues, 22(6): 756-777.

Oláh, L. Sz. 2001. "Gender and family stability: dissolution of the first parental union in Sweden and Hungary," Demographic Research [online], 4(2): 29-96. http://www.demographic-research.org/Volumes/Vol4/2/42.pdf.

Ono, H. 1998. "Husbands' and wives' resources and marital dissolution," Journal of Marriage and the Family, 60: 674-689.

Oppenheimer, V. K. 1997. "Woman's employment and the gain to marriage: the specialization and trading model," Annual Review of Sociology, 23: 431-453.

Risman, B.J. \& Johnson-Sumerford, D. 1998. "Doing it fairly: A study of postgender marriages," Journal of Marriage and Family, 60 (1): 23 40 . 
Guiping Liu and Andres Vikat

Rogers, S.J. 1999. "Wives' income and marital quality: are there reciprocal effects?" Journal of Marriage and the Family, 61(1): 123-132.

Rogers, S.J. 2004. "Dollars, dependency, and divorce: four perspectives o the role of wives' income," Journal of Marriage and Family, 66 (1): 5974.

Ross, H. L. \& Sawhill, I. V. 1975. Time of transition. Washington, D. C.: The Urban Institute.

Sayer, L. C. and Bianchi, S.M. 2000. "Woman's economic independence and the probability of divorce -- A review and reexamination," Journal of Family Issues, 21(7): 906-943.

Sørensen, A. \& McLanahan, S. 1987. "Married women's economic dependency, 1940-1980.” American Journal of Sociology, 93(3): 659-687

Spitze, G \& South, S. J. 1985. "Woman's employment, time expenditure, and divorce." Journal of Family Issues, 6(3): 307-329.

Statistics Sweden. 1995. "Skilsmässor och separationer: Bakgrund och utveckling," [Divorces and Separations: Background and Development] Demografiska rapporter, 1995(1). Örebro: Statistics Sweden.

Sundström, M. \& Duvander, A.-Z. E. 1999. Family division of child care: why do- or don't - Swedish fathers take parental leave? Stockholm Research Reports in Demogrpahy, No.139. Stockholm, Sweden.

Thomson, E., Hoem, J. M., Vikat, A., Prskawetz, A., Buber, I., Toulemon, L., Henz, U., Godecker, A. L. \& Kantorová, V. 2002. Childbearing in Stepfamilies: How Parity Matters. In E. Klijzing \& M. Corijn [Eds.], Fertility and Partnership in Europe: Insights and Lessons from Comparative Research. Geneva/ New York: United Nations.

White, L. \& Rogers, S.J. 2000. "Economic circumstances and family outcomes: A review of the 1990s." Journal of Marriage and Family, 60: 10351051 . 